\title{
Techno-economic comparison of technology options for deep decarbonization and electrification of residential heating.
}

\author{
M. J. S. Zuberi $\odot$ J. Chambers • M. K. Patel
}

Received: 29 January 2021 / Accepted: 7 August 2021 / Published online: 20 September 2021

(C) The Author(s) 2021

\begin{abstract}
This study aims to provide detailed information on the key technologies that utilize renewables for decarbonization and electrification of the residential heating sector. To contextualize and compare the economics of the technologies, a levelized cost model is employed to perform a comparative analysis for a dense urban area in Switzerland. The outcome shows that decarbonization of the heat supply with a dominant share of renewables is feasible, but it is challenged by the high cost of some options. In the given context (current energy and $\mathrm{CO}_{2}$ prices, no coercive measures), the rapid shift from conventional boilers to electrification via decentralized heat pumps and/or the introduction of targeted small-scale thermal energy networks utilizing cheap local resources like industrial excess heat is the most viable option. The replacement of natural gas boilers with electrification technologies also is recommendable because it would result in a sixfold reduction in specific $\mathrm{CO}_{2}$ emissions. Wide-scale application of heat pumps
\end{abstract}

Highlights Decarbonization and electrification options are studied for residential heat supply.

Renewable heat supply is feasible but challenged by the high cost of some options.

To accelerate the energy transition, policy interventions are needed.

M. J. S. Zuberi $(\bowtie) \cdot$ J. Chambers $\cdot$ M. K. Patel

Department F.-A. Forel for Environmental and Aquatic

Sciences, Chair for Energy Efficiency, University

of Geneva, Uni Carl-Vogt, 1205 Genève, Switzerland

e-mail: Jibran.Zuberi@unige.ch may require significant electricity grid reinforcement which ultimately may escalate the costs. Largescale district heating systems are currently relatively expensive due to the high network costs and require a sustainable financing mechanism. To speed up the energy transition, policy interventions by the government are urgently needed.

Keywords Decarbonization - Electrification . Residential heating · Heat pump · District heating · Levelized costs $\cdot$ Switzerland

\section{Introduction}

Climate change poses immense environmental, social, and economic risks to the world and threatens to undo decades of improvements to human quality of life. To address climate change, deep emission reductions of greenhouse gas emissions and in particular of $\mathrm{CO}_{2}$ emissions from the current energy systems are inevitable. In the Paris Agreement, the target was set to limit the increase in mean surface temperature to less than 2 ${ }^{\circ} \mathrm{C}$ compared to preindustrial levels. To ensure a probability beyond two-thirds of achieving the target, the global cumulative $\mathrm{CO}_{2}$ emissions must remain in the range of 550-1300 Gt by 2050 (SDSN/IDDRI 2014). Hence, the agreement calls on countries to intensify their efforts to achieve net-zero $\mathrm{CO}_{2}$ emissions globally by 2050 . The ambitious goal requires each country to reshape its energy systems to run mostly on 
renewables, in combination with improved energy efficiency. This transition primarily requires reducing energy demand by minimizing energy waste, decarbonizing electricity and heat supply, and using renewable electricity to fulfill a large share of the energy demand (Newton and Tucker 2011). So far, very few countries including Switzerland have taken drastic measures in this regard. According to its Energy Strategy 2050 (ES 2050), Switzerland aims to reduce its total final energy demand by $22-46 \%$ in 2050 compared to the level in 2010 under different policy scenarios (Prognos 2012). The residential sector, which accounts for nearly $28 \%$ of the total final energy demand in Switzerland (of which $70 \%$ is utilized for space heating and hot water production in conventional fossil fuel boiler systems; BFE 2018; Streicher et al. 2018), can play a major role to achieve the goal.

Low-carbon technologies deployed in either centralized or (district heating networks, DHN) or decentralized systems are required to decarbonize energy production and consumption. Many technologies that can reduce the carbon footprint of the residential heating sector are technically mature and commercially available but have higher costs than the fossil fuel-based alternatives (Connolly et al. 2014; Danish Energy Agency 2020). In many national and regional contexts, the existing technologies may not be sufficient to achieve deep decarbonization, and emerging innovative technologies that are currently demonstrated in small commercial niches must be tabled as potential future solutions. While there has been significant progress in the development of new technologies, substantial work remains to scale up solutions and realize large-scale deployment. Despite being technically viable, some options are too expensive for mass adoption (Bloess et al. 2018; SDSN/ IDDRI 2014). A systematic and detailed techno-economic assessment of the current pool of technologies, together with the discussion on barriers including public concern about safety, reliability, and environmental impacts, is hence essential.

Many countries foresee decarbonization of electricity generation and electrification of energy end uses as a key strategy for deep decarbonization. The impact of electrification of the energy end-use (such as heat pump application for space heating) cannot be significant if the electricity generation remains $\mathrm{CO}_{2}$-intensive. Simultaneous decarbonization of the power sector is hence a prerequisite for reducing the
$\mathrm{CO}_{2}$ impact of the economic sectors including residential (Leibowicz et al. 2018; Timmons et al. 2016). On the other hand, extensive electrification of the heat supply may need reinforcement of the existing electricity grid distribution and transmission, hence incurring additional costs (Element Energy \& E4tech 2018).

Sustainable Development Solutions Network of the United Nations (UN) initiated a project comprising of 15 country research partners from all continents to primarily demonstrate how individual countries (both developed and developing) can decarbonize their energy systems. Each partner country developed a deep decarbonization pathway showing a substantial cut in the $\mathrm{CO}_{2}$ intensity of their residential sector by increasing electrification for heat supply and the use of solar thermal energy, and combined heat and power (CHP) (SDSN/IDDRI 2014). For example, Pye and Anandarajah (SDSN/ IDDRI 2014) demonstrated that electrification of the residential heating sector plays a significant role in the United Kingdom (UK) for rapidly decreasing the use of natural gas in 2050, although the degree of its role can be balanced against other options including biomass, solar thermal, and district heating. Zhang et al. (2019) studied the case of Beijing, China, to decarbonize the city's heating system. They also concluded that electrification through rapid deployment of decentralized heat pumps is better aligned with Beijing's target of a low-carbon heating sector. On the contrary, Lund et al. (2010) compared the impacts of different decentralized and centralized heating options on fuel use and $\mathrm{CO}_{2}$ emissions for the Danish energy system in the long term. They concluded that a gradual expansion of the district heating network in areas within a $1 \mathrm{~km}$ distance from the existing networks together with the individual heat pumps in the remaining areas is the most cost-effective option in the future $100 \%$ renewable energy system. Kontu et al. (2019) analyzed the economic viability of large heat pumps in district heating systems for decarbonizing the Finnish heating sector. Their results show that the largest potential for heat pumps is in small thermal networks. For medium and large networks, CHP technologies are more suitable. Zuberi et al. (2021) performed a detailed enviro-economic assessment of the application of heat pumps and DHN in different Swiss building archetypes on different scales. 
Table 1 Energy

efficiencies of biomassbased heat and power generation technologies (Source: Danish Energy Agency 2020).

\begin{tabular}{lllll}
\hline Technology & $\begin{array}{l}\text { Electric effi- } \\
\text { ciency }(\%)\end{array}$ & $\begin{array}{l}\text { Heat efficiency } \\
(\%)\end{array}$ & $\begin{array}{l}\text { Overall effi- } \\
\text { ciency }(\%)\end{array}$ & Typical capacity \\
\hline Wood chip CHP & 28 & 55 & 83 & $25-170 \mathrm{MW}_{\mathrm{e}}$ \\
Wood pellet CHP & 32 & 33 & 65 & $25-255 \mathrm{MW}_{\mathrm{e}}$ \\
Straw CHP & 30 & 39 & 69 & $25-40 \mathrm{MW}_{\mathrm{e}}$ \\
Wood chip HOB & - & - & 90 & $7 \mathrm{MW}_{\text {th }}$ \\
Wood pellet HOB & - & - & 90 & $6 \mathrm{MW}_{\text {th }}$ \\
Straw HOB & - & - & 75 & $6 \mathrm{MW}_{\text {th }}$ \\
Stirling engines & 22 & 66 & 88 & $40 \mathrm{~kW}_{\mathrm{e}}$ \\
\hline
\end{tabular}

Their results show that the economic viability of different heating technologies significantly overlaps with each other under various conditions and is sensitive to heating system design configurations and linear heat density.

While it is evident from the literature review that decarbonization of the residential heat supply is possible economically, it is not clear which of the several existing and emerging technologies and their combinations should be favored. For designing lowcarbon energy solution packages at the regional and national scales for a clean energy transition and the modeling of net-zero emission scenarios in the context of the Paris Agreement, researchers must have a comprehensive overview of the technological options and their associated socio-economic indicators. This work provides researchers and policymakers with extensive information about key technologies that utilize renewable energy resources for the decarbonization of the residential heating sector. To contextualize and compare the economic viability of the technical solutions, a simple model for calculating the levelized costs of energy is developed and a case study for the buildings in the canton of Geneva that are already connected to the heat network is performed. In the next section, the technology options for the residential heat supply are described. The methods used for estimating the potential of different renewable energy resources and for developing the cost models are discussed in "Materials and methods." In the following section, the results of the technology review and the extent to which these can be deployed are presented. In the same section, the levelized costs are compared and the costs of grid reinforcement as a consequence of electrification of the heating sector are discussed. Brief conclusions are given in the final section.

\section{Technology options for the residential heating sector}

Centralized solutions

\section{Biomass-based technologies}

Biomass-based technologies considered in this study include CHP and heat-only plants that convert wood chips, pellets, or straw. In a typical CHP plant with a steam turbine (as also assumed in this study), biomass is combusted in a boiler to produce high-pressure steam and is expanded through a turbine to generate power while the turbine by-pass and the boiler flue gases are utilized for district heating. In a heat-only boiler (HOB), the output is hot water which is used directly for district heating (Danish Energy Agency 2020). Since the aforementioned forms of biomass differ in terms of humidity, density, ash content and composition, granularity, and grindability, efficiencies of CHP and HOB vary accordingly; refer to Table 1.

An emerging CHP technology considered in this study is the Stirling engine fired by gasified biomass. A Stirling engine is driven by the difference in temperatures created by external heating and cooling sources. The technology includes an engine filled with a working gas (Helium in this case) heated by the flue gases of biomass combustion and cooled by cooling water. More specifically, biomass (such as wood or straw) is gasified to form gas, which is directed to a combustion chamber coupled to a Stirling engine (Danish Energy Agency 2020). The gas is combusted in the chamber and the resulting flue gases heat the Stirling engine which drives an electricity generator. The 
typical electric capacity of a Stirling engine today is $40 \mathrm{~kW}(120 \mathrm{~kW}$ heat) which is well below the typical heat demand of dense urban areas including the case study region. Hence, depending on the availability of biomass resources, several Stirling engines would be needed to fulfill part of the heat demand.

\section{Geothermal with heat pump}

A geothermal plant for district heating consists of a set of wells, a heat exchanger, and a heat pump (without a heat pump if the temperature of the geothermal source is sufficiently high). The plant pumps hot water from the underground water reservoirs at a temperature below $100{ }^{\circ} \mathrm{C}$ and the heat is extracted using a heat exchanger. The hot water after heat exchange is returned to the reservoir. Heat pumps are used to upgrade heat to the demand temperature. In this study, sufficient geothermal heat resources are assumed to be available in the case study region based on the fact that the local utility company (Services Industriels de Genève, SIG) has anticipated large potential in Geneva and is currently drilling geothermal wells up to $2 \mathrm{~km}$ depth (République et Canton de Genève 2018). Since the geothermal heat source and return temperatures are assumed at $70{ }^{\circ} \mathrm{C}$ and $17{ }^{\circ} \mathrm{C}$ respectively based on Danish Energy Agency (2020), heat pumps will be required to upgrade the heat to the demand temperature (see "Case study"). Since the production of geothermal heat leads to temperature and pressure gradients, one way to sustain production over longer periods is the regeneration of the geothermal reservoir by reinjecting an adequate amount of heat from a different source at regular intervals (World Energy Council 2013). Solar resources, which due to variability are not suitable to fulfill the entire district heat demand (see later), could be harvested whenever available to regenerate the geothermal wells from time to time.

\section{Solar thermal collectors}

Solar energy to heat water has been in use for many years and more than 580 million $\mathrm{m}^{2}$ of solar collectors with an installed thermal capacity of $410 \mathrm{GW}$ are currently in operation worldwide (REF). The majority of the capacity represents small-scale domestic hot water systems; however, there has been some growth in the past years for large-scale systems mainly for district heating (Danish Energy Agency 2020). For district heating, the collectors are usually mounted on the ground in long rows connected in series, absorbing heat from the sun and heating the water that returns from the DHN to the desired supply temperature. Flat plate collectors (FPC) and evacuated tubular collectors (ETC) are the two most common types. While ETC are more efficient than FPC at higher temperatures, they are also more expensive (Danish Energy Agency 2020). FPC with an assumed efficiency of $45 \%$ is considered in this study not only because they are relatively cheaper but also because of the large operational experience, e.g., in Scandinavian countries.

\section{Industrial excess heat recovery}

A significant amount of heat from industrial systems is lost to the environment in the form of flue gases and other process streams. Depending on the level of process heat integration possible in an industrial plant, the remaining heat at suitable temperatures can be recovered and used for district heating. In Switzerland, significant volumes of industrial excess heat (IEH) remain unutilized. Zuberi et al. (2018) presented an overview of the spatial distribution of the excess heat recovery potential by temperature level in the Swiss industry. The study highlights different areas of the country with high levels of potential excess heat at temperatures higher than the demand, part of which can be fed to district heating networks via heat exchangers (see "Industrial excess heat").

\section{Solid oxide fuel cell combined heat and power}

Solid oxide fuel cell (SOFC)-based CHP is a relatively new concept and not many such plants are currently in operation for district heating around the globe. The system considered in this study uses natural gas or renewable biogas as fuel and can be easily connected to the gas grid similar to conventional natural gas boilers. SOFC-CHP can also utilize syngas, hydrogen, liquefied petroleum gas (LPG), or diesel as fuel (Danish Energy Agency 2020). In the system, ambient air enters the fuel cell from the cathode side while the fuel-steam mixture enters from the anode side to produce reformed gas. As the reformed gas passes through the anode, oxygen ions are attracted to it from the cathode and combined to produce 
electricity, steam, and $\mathrm{CO}_{2}$. The steam that is produced in the electrochemical process is recycled for fuel reforming hence not requiring water during normal operation (Ballantine 2019). The fuel cell is operated at high temperatures $\left(600-700{ }^{\circ} \mathrm{C}\right)$ and part of the heat is used to drive the reforming reaction while the surplus can be used for district heating (Ballantine 2019; Danish Energy Agency 2020). While the currently installed systems are small scale and focus mainly on providing power, the system can be designed to meet the district heating demand (Danish Energy Agency 2020). In this study, the electrical and heat efficiencies for SOFC-CHP are assumed at 58\% and $32 \%$.

\section{Decentralized solutions}

\section{Biomass boiler systems}

As an alternative to conventional natural gas boilers, biomass boilers can be employed for domestic heat supply. Automatically stoking biomass boilers are typically supplied with wood pellets; however, some are also designed for firing with other biomass types such as wood chips and straw (Danish Energy Agency 2018). Biomass wood boilers can be a standalone solution for heat supply but hybrid systems such as solar biomass are an attractive combination, as also considered in this study. During summer, hot water demand can be met by solar thermal, while biomass boilers could cover the rest of the heating demand throughout the year. Since biomass waste resources such as straw might be difficult to utilize for decentralized heating due to unavailability and logistic reasons, wood boilers with an efficiency of $90 \%$ are hence considered.

\section{Electric heat pumps}

Heat pumps allow upgrading heat from low-temperature sources to useful high-temperature heat. Among the different types of heat pumps, the most conveniently applied and widely used for building applications are electric heat pumps (Industrial Heat Pumps n.d.). Depending on the heat source, electric heat pumps can be further classified into air source (ASHP), ground source (GSHP), and water source heat pumps (WSHP). ASHP extracts heat from the ambient air and supplies it locally through
Table 2 SPF of different types of heat pumps (Source: Zuberi et al. 2021)

\begin{tabular}{lc}
\hline Type of heat pump & SPF \\
\hline Air source heat pump (ASHP) & 3.0 \\
Water source heat pump (WSHP) & 4.0 \\
Ground source heat pump (GSHP) & 3.7 \\
\hline
\end{tabular}

an air-to-air/water heat exchanger. Contrary to this, WSHP draws heat from a water reservoir (e.g., lake, river, and groundwater) and supply domestic heat through a water-based distribution system. GSHP uses horizontal pipes ${ }^{1}$ containing anti-freeze brine which is circulated to extract heat from the upper soil layers (Danish Energy Agency 2018). The thermal efficiency of ASHP over a given period (represented by the seasonal performance factor (SPF)) is typically lower than the other two types (refer to Table 2), due to the relatively high-temperature lift when upgrading ambient heat from the air to the demand temperature. However, ASHPs are rather easy to install and hence cheaper (Zuberi et al. 2021). Typically, ASHPs have relatively small capacities (Zuberi et al. 2021); hence, they are only considered for decentralized heating.

\section{Roof-mounted solar collectors}

At the building level, solar heating is mainly designed to cover the entire hot water demand during summer (baseload). The renewable source can be utilized by pumping a heat transfer fluid (typically a water-glycol mixture) from an array of roof-mounted solar collectors to one or more storage tanks. However, due to the mismatch between the space heating demand and available solar heat resources, seasonal energy storage will be needed if solar energy needs to be the only supply (Danish Energy Agency 2018). Since seasonal storage is outside the scope of this study and the authors have investigated it in detail separately (Narula, De Oliveira Filho, et al. 2020; 2020b), in this study, solar energy is considered in combination with

\footnotetext{
${ }^{1}$ It is also possible to employ vertical pipes installed in depths of up to $250 \mathrm{~m}$. However, such GSHP configuration is primarily used when the surface is not suitable (e.g., rocky grounds) for the installation of horizontal pipes. GSHP with vertical pipes is also very expensive (Danish Energy Agency 2018).
} 


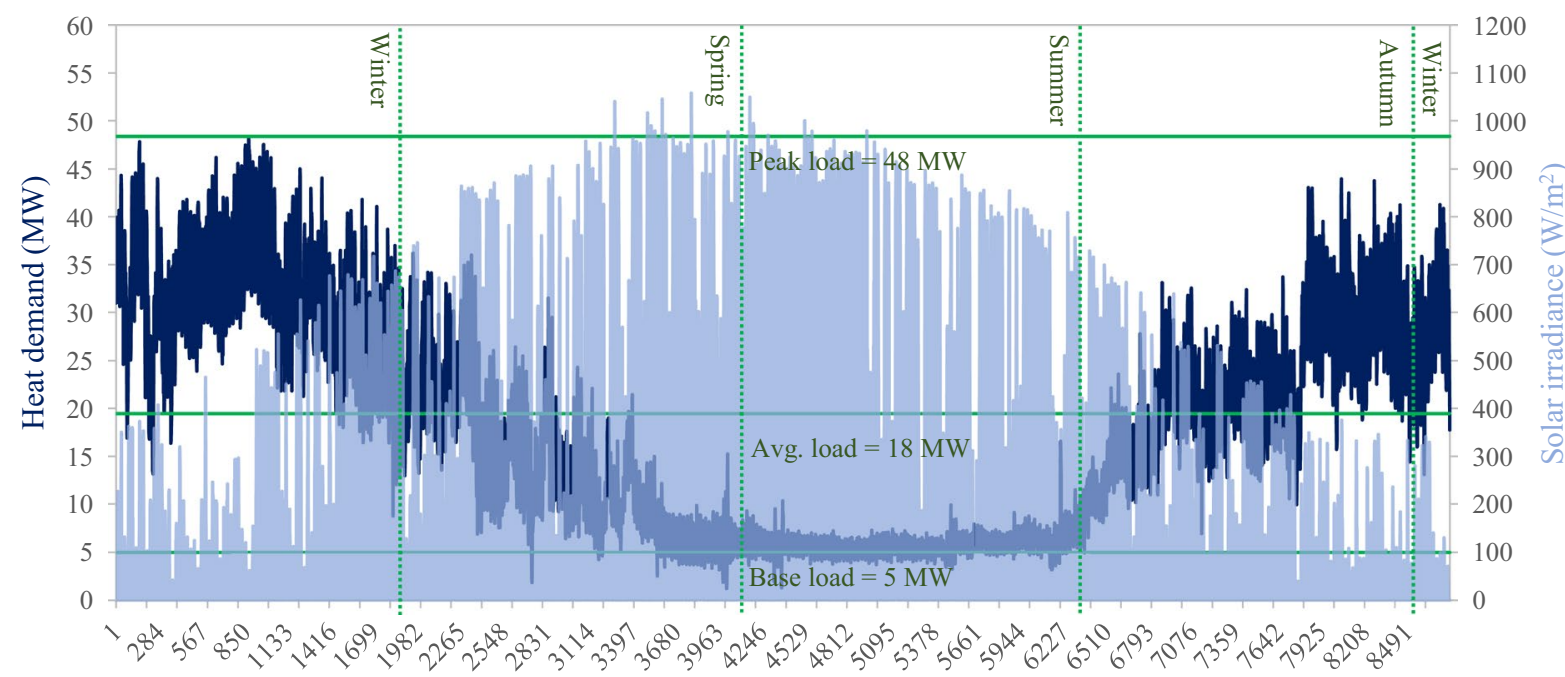

Hours

Fig. 1. Hourly heat demand of approx. 20,000 households and solar irradiance in Geneva in 2015 (MeteoSwiss 2018; Schneider et al. 2019; STIG 2015)

biomass boilers (as mentioned earlier) to fulfill the baseload heat demand.

\section{Materials and methods}

Case study

To compare the costs of centralized and decentralized heat supply technologies on a given basis, Geneva is considered as the case study region where two DHN are already in operation and further being expanded, next to a combined district cooling and heating network (SIG 2019). Buildings in Geneva have a fairly typical energy use intensity for Switzerland (on average $93 \mathrm{kWh} / \mathrm{m}^{-2}$ p.a. (Streicher et al. 2019)). Fig. 1 presents the hourly heat demand profile (for the base year 2015) of approximately 20,000 households located in the Geneva region served by the so-called CADIOM network (Quiquerez 2017). The base year 2015 is considered representative of a typical climate year (with 1250 heating degree-days, using the standard base temperature of $12{ }^{\circ} \mathrm{C}$ for Switzerland (Streicher et al. 2019)) in Switzerland, and hence, several analyses have been organized around this year. The heat profile shows significant changes in heat demand over time. Needless to say, most of the heat demand occurred in the winter months while in summers, the demand was low and did not fluctuate much. The peak hourly heat demand during the coldest period was $48 \mathrm{MW}$ which is almost 10 times higher than the baseload of approximately $5 \mathrm{MW}$ in summers. For sizing the heating systems, peak hourly heat demand is considered. Investment, operation and maintenance, and energy costs are estimated based on the heat demand profile shown in Fig. 1. The heat supply and return temperatures are assumed at $80{ }^{\circ} \mathrm{C}$ and 40 ${ }^{\circ} \mathrm{C}$, respectively.

Energy resources for heat generation

\section{Biomass}

Its broad availability and utilization options make biomass an attractive renewable energy solution also for decarbonizing the residential heating sector. Biomass includes many different sources including livestock, crop residues (e.g., straw), domestic wastes, and bagasse. Given the availability and reliability of the resources in the case study region, only livestock and agricultural wastes are considered. Only the local biomass is considered for the analysis based on the assumption that other cantons in Switzerland as well as other European countries might also want to use their biomass resources for heat generation in the future. The livestock waste biomass model is 
Table 3 Input values for various factors to estimate the energy potential of livestock waste in Geneva (Source: FSO 2019, Batzias et al. 2005).

\begin{tabular}{llllll}
\hline Livestock & No. of heads & $\begin{array}{l}\text { Dry solids } \\
\text { (t/head/yr) }\end{array}$ & $\begin{array}{l}\text { Availabil- } \\
\text { ity factor }\end{array}$ & $\begin{array}{l}\text { Biogas yield } \\
\text { factor }\left(\mathrm{m}^{3} /\right. \\
\text { dry t })\end{array}$ & $\begin{array}{l}\text { Energy fac- } \\
\text { tor (MWh/ } \\
\left.\mathrm{m}^{3}\right)\end{array}$ \\
\hline Beef cattle and cows & 2755 & 1.54 & 0.45 & 281 & 0.006 \\
Horses and other equines & 1221 & 2.60 & 0.10 & 160 & 0.006 \\
Sheep & 2228 & 0.22 & 0.35 & 120 & 0.006 \\
Goats & 195 & 0.22 & 0.35 & 120 & 0.006 \\
Pigs & 1247 & 0.22 & 0.80 & 649 & 0.006 \\
Poultry & 50,362 & 0.01 & 0.70 & 359 & 0.006 \\
Other animals & 1952 & 0.03 & 0.05 & 359 & 0.006 \\
Total & 59,960 & 4.84 & & & \\
\hline
\end{tabular}

established based on the methodology presented by Batzias et al. (2005) and Ali et al. (2015). Using the input values for various factors presented in Table 3 , the total energy potential of the livestock waste $E_{\text {lsw }}$ in Geneva can be determined using Eq. 1:

$E_{l s w}=\sum\left(N_{s} \times D S_{s} \times f_{a} \times Y_{s} \times f_{e}\right) \times \eta_{p}$

where

$N_{\mathrm{s}} \quad$ Number of heads of an animal species $s$.

$D S_{\text {s }}$ Annual dry solids production per head of an animal species $s$ (t/head/yr).

$f_{\text {a }} \quad$ Availability factor (amount of waste of an animal species that can be collected per annum).

$Y_{\mathrm{s}} \quad$ Biogas yield per unit of dry solids production per head of an animal species $s\left(\mathrm{~m}^{3} /\right.$ dry $\left.\mathrm{t}\right)$.

$f_{\mathrm{e}} \quad$ Energy factor (energy content per unit of biogas produced in $\mathrm{MWh} / \mathrm{m}^{3}$ ).

$\eta_{\mathrm{p}} \quad$ Total plant efficiency (\%).

The agricultural waste biomass model is developed based on the information given by Steubing et al. (2010) and the Federal Statistical Office (FSO 2019). The total energy potential of the crop residues $E_{\text {cr }}$ in Geneva can be calculated by Eq. 2:

$E_{c r}=C R \times A U \times U \times f_{s t} \times \eta_{p}$

where

CR Annual crop residues per hectare of arable land (taken as 2.2 dry t/ha).

$A U$ Ratio of the arable land and the utilized agricultural area in Geneva (estimated as 0.6 approx.)
$U$ Total utilized agricultural area in Geneva (approx. 11,300 ha).

$f_{\mathrm{e}} \quad$ Energy factor (energy content per unit of crop residues assumed as $0.28 \mathrm{MWh} / \mathrm{dry} \mathrm{t}$ ).

$\eta_{\mathrm{p}} \quad$ Total plant efficiency (\%).

Depending on whether the crop residues are combusted directly (e.g., in straw CHP or HOB) or fermented to produce biogas as an intermediate step (as required in Stirling engine or SOFC), the final energy output could slightly vary (Mazurkiewicz et al. 2019; Zbytek et al. 2016). Considering the thermal efficiency of the heat generation technology, refer to Table 1, and the efficiency of the bio-waste fermenter and biogas upgrade facility (taken as $90 \%$ based on Panos and Kannan 2016), the total contribution of the estimated livestock and agricultural waste resources in the annual heat demand of the households (refer to Fig. 1) could be up to $33 \%$. To fulfill the remaining demand, a backup system (e.g., wood-based CHP or HOB) must be installed.

\section{Solar}

The heat generated from solar energy depends on solar irradiation, weather conditions, time of day, and the season of the year (Danish Energy Agency 2018). The average hourly solar irradiation in the Geneva region is presented in Fig. 1. The seasonal variation can be compensated using seasonal storage which is outside the scope of this study (see earlier). The solar thermal plant including diurnal heat storage is sized for the baseload demand, i.e., $5 \mathrm{MW}$. Eq. 3 is used to obtain the solar heat generation at every hour over an entire year $E_{\text {sol. }}$. The typical plant size for centralized 
solar district heating is $13,000 \mathrm{~m}^{2}$ (Danish Energy Agency 2018) which means multiple plants at various locations would be needed to fulfill the baseload demand. At the building level, $20 \mathrm{~m}^{2}$ is the typical collector size. However, either centralized or decentralized, available land area and roof area could be a limiting factor in solar thermal energy utilization for residential heating respectively.

$E_{\text {sol }}=I_{\text {sol }} \times A_{c o l} \times \eta_{p}$

where

$I_{\text {sol }} \quad$ Hourly solar insolation on the collector surface $\left(\mathrm{W} / \mathrm{m}^{2}\right)$.

$A_{\text {col }} \quad$ Area of solar collectors $\left(\mathrm{m}^{2}\right)$.

$\eta_{\mathrm{p}} \quad$ Total plant efficiency, taken as $45 \%$.

\section{Industrial excess heat}

Zuberi et al. (2018) applied a method to combine GIS mapping and energy system modeling to estimate excess heat in the Swiss industry. The study estimated a total of approx. $80 \mathrm{GWh}$ of industrial excess heat at temperatures above $100{ }^{\circ} \mathrm{C}$ is available in the canton of Geneva. This corresponds to almost $50 \%$ of the total heat demand of the households in Fig. 1. However, Chambers et al. (2020) further expanded the analysis to investigate the spatiotemporal matching of the households' monthly heat demand and IEH supply in the Swiss residential sector including Geneva. The authors showed that spatiotemporal matching leads to lower IEH utilization potential. For Geneva, which is a relatively small and densely populated canton, it is assumed that a maximum of $25 \%$ of the total IEH potential could be utilized for residential heating.

Levelized costs of heat

The costs of heat supply by various technologies for residential heating ${ }^{2}$ are calculated in terms of the Levelized cost of heat ( $\mathrm{LCOH})$ which is a useful method to compare and benchmark these technologies that differ in cost structures and operating lifetimes (Hansen 2019). LCOH is determined by the

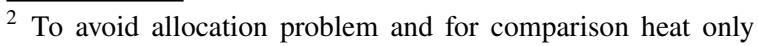
technologies, the levelized costs for CHP are calculated per unit of energy supply, i.e., heat + electricity.
}

following equations. This study employs a discount rate of 3\% for annualizing the total investment costs of all energy supply technologies.

$L C O H=\frac{a \cdot I_{x}+O \& M_{x}+E_{x}}{Q}$

where

a. $I_{x} \quad$ Annualized investment costs of technology $x(\mathrm{CHF} / \mathrm{yr})$.

$O \& M_{x} \quad$ Annual fixed and variable operations and maintenance cost of technology $x(\mathrm{CHF} / \mathrm{yr})$.

$E_{x} \quad$ Annual energy costs of technology $x(\mathrm{CHF} /$ yr).

$Q \quad$ Annual useful heat demand for residential space heating and hot water production (kWh/yr).

$a=\frac{(1+r)^{L} \times r}{(1+r)^{L}-1}$

where $r$ and $L$ are the discount rate and lifetime (ranging between 20 and 25 years with an exception of 30 years for building scale electric boiler) of the energy supply technologies respectively.

Further input data

For district heating systems, the heat distribution network $^{3}$ costs contribute significantly to the total costs. Zuberi et al. (2021) recently developed a detailed model for the estimation of the network costs which has also been used in this study to estimate the total costs of DHN (i.e., investment, O\&M, and energy costs of heat production and distribution). The investment and O\&M costs of the different technologies collected from different sources (see "Cost data for heat generation technologies") are adapted to a higher cost level in Switzerland by using the labor and material cost correction factors given by IRENA (IRENA 2017).

Since there is uncertainty about excise taxes, renewables' share in power generation, subsidies, and energy and $\mathrm{CO}_{2}$ policies in the future, fixed

\footnotetext{
$\overline{3 \text { Components }}$ of a heat distribution network are pipes, trenches, pumps, controls, water treatment, water tanks for thermal storage, etc.
} 
Table 4 Prices and $\mathrm{CO}_{2}$ emission factors of energy carriers.

\begin{tabular}{lll}
\hline Energy carrier & $\begin{array}{l}\text { Price }(\mathrm{BFE} \\
2018) \\
(\text { cents/kWh) }\end{array}$ & $\begin{array}{l}\text { Emission factor } \\
(\mathrm{BAFU} 2016 ; \text { FOEN } \\
2018) \\
\left(\mathrm{kgCO}_{2} / \mathrm{kWh}\right)\end{array}$ \\
\hline Natural gas & & 0.20 \\
Electricity & 9.3 & 0.14 \\
Wood & 20.1 & 0 \\
Biomass (excl. wood) & 3.0 & 0 \\
Industrial excess heat & 5.0 & 0
\end{tabular}

${ }^{*}$ The price for natural gas includes a $\mathrm{CO}_{2}$ levy, i.e., $96 \mathrm{CHF} / \mathrm{t}$ $\mathrm{CO}_{2}$.

Table 5 Electricity grid reinforcement costs to support peak electricity supply (Source: National Infrastructure Commission, UK (Element Energy \& E4tech 2018)).

\begin{tabular}{lll}
\hline Range & $\begin{array}{l}\text { Transmission network } \\
\left(\mathrm{CHF} / \mathrm{kW}_{\text {peak }}\right)\end{array}$ & $\begin{array}{l}\text { Distribution } \\
\text { network }(\mathrm{CHF} / \\
\left.\mathrm{kW}_{\text {peak }}\right)\end{array}$ \\
\hline Maximum & 271 & 772 \\
Mean & 185 & 628 \\
Minimum & 98 & 484 \\
\hline
\end{tabular}

energy prices are used in this study and are presented in Table 4. The table also presents the emission factors of the energy carriers which are used to estimate the $\mathrm{CO}_{2}$ emissions from different heating technologies. Whether the IEH is recovered and utilized for district heating or not, it will anyway occur on the industrial site due to process inefficiencies (which can be reduced by industrial energy efficiency improvement). Moreover, the excess heatrelated $\mathrm{CO}_{2}$ emissions have already been accounted for in the manufacture of the industrial process; hence, no emission factor is assigned to IEH and is considered renewable.
Electrification using heat pumps enables deep decarbonization of the residential heating sector in the future and is arguably the only proven and mature technology for the wide-scale application. However, both technologies are currently having a low level of deployment in the Swiss residential sector. Increasing the share of electric heat pumps in the overall heat supply would need reinforcement of the existing electricity grid distribution and transmission, hence requiring additional investments. These costs have been estimated for Switzerland based on the costs estimated by a study for the UK (Element Energy \& E4tech 2018). The cost adaptations for reinforcing the electricity grid to support peak electricity supply are presented in Table 5.

\section{Results and discussion}

Potential energy resources

For decentralized heating technologies, the availability of renewable heat sources is subject to varying constraints, which may be technical or rather societal. For ground or water source heat pumps, not all subsoil regions are equally suitable, or longer transport lines for water may be needed to reach a resource, which is not always feasible. Air source heat pumps face fewer constraints (exceptions are noise and space constraints in dense urban areas), as does the transport of biomass-derived fuels. However, given that these are largely not energy balance constraints and the fine-grained analysis needed to address them, they are not considered in this paper.

The renewable sources considered for centralized heating including biomass waste, IEH, and solar are
Table 6 Potential energy resources for current district heating network.

The values shown in the table do not take into account the efficiency of the heating system except for solar thermal.

\begin{tabular}{|c|c|c|}
\hline \multirow[t]{2}{*}{ Energy resource } & \multicolumn{2}{|l|}{ Potential contribution } \\
\hline & $\begin{array}{l}\text { Heat supply potential }{ }^{1}(\mathrm{MWh} / \\
\mathrm{yr})\end{array}$ & $\begin{array}{l}\text { Relative (\% of the annual } \\
\text { heat demand of current } \\
\text { DHN) }\end{array}$ \\
\hline Livestock & 4790 & $3 \%$ \\
\hline Straw & 58,300 & $45 \%$ \\
\hline Industrial excess heat & 20,000 & $13 \%$ \\
\hline Solar & 14,250 & $9 \%$ \\
\hline
\end{tabular}


subject to availability. Based on the methods outlined in "Energy resources for heat generation," the potential contribution of each renewable source is estimated and presented in Table 6. After considering the heating system efficiencies, the resources listed in the table could potentially contribute a maximum of up to $50 \%$ of the total heat demand of the given number of households in Geneva; therefore, a backup system will be needed. Wood-based systems could serve the purpose because of the flexibility of using a different source of wood. Since the exploration of geothermal resources is still underway in Geneva, a precise estimate of the potential cannot be made at this stage. The assumption of enough geothermal potential based on the preliminary drilling results to satisfy the given household demand is hence optimistic.

\section{Cost data for heat generation technologies}

Based on the primary data sources (Danish Energy Agency 2018, 2020; Klinke 2018; Panos and Kannan 2016; Quiquerez 2017; Sandvall et al. 2017) (largely dominated by the data disseminated by the Danish Energy Agency), the generalized data for the investment and O\&M costs of the centralized and decentralized heating technologies and their combinations are developed and shown in Table 7 . To the best knowledge of the authors, the list shown in Table 7 is by far among the most comprehensive in the scientific literature for district heat generation technologies including emerging systems like SOFC-CHP and Stirling engines operated on gasified biomass and small-scale building-level technologies for space heating and hot water supply. As mentioned earlier, whether the IEH is utilized for district heating or not, it will be generated on the industrial site due to process inefficiencies; hence, the generation costs of IEH are considered zero, and only the price at which the IEH is assumed to be sold to a utility is taken into account. The specific investments (levelized over the lifetime) and O\&M costs of the heat distribution network in Geneva (based on the linear heat density assumed as $5 \mathrm{MWh} / \mathrm{m}$; refer to "Further input data" for details and references) are estimated at $0.5 \mathrm{CHF} /$ $\mathrm{kWh}$ and $0.02 \mathrm{CHF} / \mathrm{kWh}$, respectively. The specific input cost data in Table 7 are used to calculate and compare the technology-specific levelized costs of energy (LCOE) in the following section.
Comparison of technology options

As previously stated, the investment costs of DHN can be broken down into two components, i.e., (i) network distribution costs including the costs of pipes and substations to transfer hot water and (ii) the costs of hot water generation which vary by production technology. If renewable energy technologies are replaced with conventional production technologies in existing networks, only the costs of heat generation need to be taken into account. However, to compare the economic viability of replacing decentralized heating technologies with centralized renewable heating systems, the network distribution costs must also be considered. The detailed comparison of the levelized cost of the district and decentralized heating technologies for the buildings in the canton of Geneva (also for the rest of the country if the shares of the renewable resources are assumed constant) is presented in Fig. 2. The levelized costs of heat for some of the technologies in Fig. 2 are comparable to the costs estimated by Zuberi et al. (2021) for Switzerland and IRENA (2017) for Germany. The results show that the levelized cost of all centralized solutions is higher than for the decentralized options. However, the argument is not true if the network distribution costs are ignored, which is justified for existing networks (see the Appendix Fig. 4). This implies that replacing decentralized heat generation with conventional natural gas boilers with new DHN is not cost-effective under current conditions (e.g., today's $\mathrm{CO}_{2}$ tax level) mainly because the network costs are very high (almost twice the generation costs). IRENA (2017) found a similar outcome for their comparison of centralized and decentralized heating solutions applicable in Germany and the United Arab Emirates (UAE).

For new DHN, the levelized costs of almost onethird of the heating options dominated by wood-based technologies and their combinations (including both $\mathrm{CHP}$ and $\mathrm{HOB}$ ) are around $0.2 \mathrm{CHF} / \mathrm{kWh}$. While the levelized costs of WSHPs also fall into the midrange, the investment cost is very high. As expected, geothermal district heat and other emerging heating technologies such as fuel cell and Stirling engines are found to be the most expensive. The results of Zuberi et al. (2021) show that DHN based exclusively on IEH could be as economical as the decentralized natural gas boiler systems due to low generation 
Table 7 The investment and O\&M cost data of centralized and decentralized heating technologies and technology combinations operated in Switzerland.

\begin{tabular}{|c|c|c|c|c|c|}
\hline Centralized heating technology ${ }^{a}$ & Energy carriers & 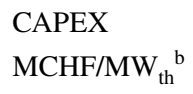 & $\begin{array}{l}\text { OPEX (fixed) } \\
\text { CHF/MW } \text { th }_{\text {p.a. }}{ }^{\text {b }}\end{array}$ & 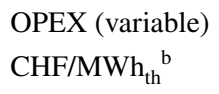 & $\begin{array}{l}\text { Lifetime } \\
\text { years }\end{array}$ \\
\hline Wood chip $\mathrm{CHP}^{1,2}$ & Wood & 5.51 & 158,473 & 7.12 & 25 \\
\hline Wood pellet $\mathrm{CHP}^{1,2}$ & Wood & 3.69 & 102,630 & 2.46 & 25 \\
\hline Straw CHP + Wood chip CHP ${ }^{1,2}$ & Straw + Wood & $5.58+5.51$ & $202,241+158,473$ & $3.23+7.12$ & 25 \\
\hline Stirling engines + Wood chip $\mathrm{CHP}^{1,2,3}$ & Biogas + Wood & $5.74+5.51$ & $48,296+158,473$ & $31.69+7.12$ & 20 \\
\hline $\operatorname{SOFC~CHP~}(\mathrm{NG})^{2}$ & NG & 4.98 & 249,028 & 0.00 & 20 \\
\hline SOFC CHP $(5 \% \text { Biogas }+\mathrm{NG})^{2,4}$ & Biogas $+\mathrm{NG}$ & $4.98+4.98$ & $249,028+249,028$ & 0.00 & 20 \\
\hline Wood pellet $\mathrm{HOB}^{1}$ & Wood & 1.08 & 49,202 & 0.85 & 25 \\
\hline Wood chip HOB ${ }^{1}$ & Wood & 1.02 & 48,145 & 1.80 & 25 \\
\hline Straw HOB + Wood chip HOB ${ }^{1}$ & Straw + Wood & $1.32+1.02$ & $76,671+48,145$ & $1.01+1.80$ & 25 \\
\hline $\mathrm{IEH}+$ Wood chip $\mathrm{HOB}^{1}$ & IEH + Wood & $0+1.02$ & $0+48,145$ & $0+1.80$ & 25 \\
\hline Solar + Wood chip HOB ${ }^{1,5}$ & Solar + Wood & $683+1.02$ & $0.14+48,145$ & $0+1.80$ & 25 \\
\hline Water source $\mathrm{HP}^{1}$ & Electricity & 2.83 & 28,250 & 0.00 & 25 \\
\hline Geothermal with $\mathrm{HP}^{6}$ & Electricity & 2.57 & 42,712 & 4.11 & 25 \\
\hline Geothermal with HP (regen.) ${ }^{5,6,7}$ & Electricity + Solar & $2.57+683$ & $42,712+0.14$ & $4.11+0$ & 25 \\
\hline Natural gas boiler & NG & 0.09 & 2943 & 1.51 & 25 \\
\hline Electric boiler (>10 MW) & Electricity & 0.11 & 1615 & 0.75 & 20 \\
\hline Decentralized heating technology ${ }^{a}$ & Energy carriers & 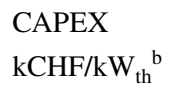 & $\begin{array}{l}\text { OPEX (fixed) } \\
\text { CHF/kW th } \text { p.a. }^{\text {b }}\end{array}$ & $\begin{array}{l}\text { OPEX (variable) } \\
\mathrm{CHF} / \mathrm{kWh}_{\mathrm{th}}{ }^{\mathrm{b}}\end{array}$ & $\begin{array}{l}\text { Lifetime } \\
\text { years }\end{array}$ \\
\hline Wood boilers & Wood & 0.39 & 5.89 & 0.00 & 20 \\
\hline Solar + Wood boilers & Solar + Wood & $0.87+0.39$ & $2.10+5.89$ & 0.00 & 20 \\
\hline Air source $\mathrm{HP}^{8}$ & Electricity & 848.04 & $1 \%$ & $0 \%$ & 20 \\
\hline Solar + Air source $\mathrm{HP}^{8}$ & Solar + Electricity & $0.87+848$ & $2.10+0.01$ & 0.00 & 20 \\
\hline Ground source $\mathrm{HP}^{8}$ & Electricity & 5414.31 & $1 \%$ & $0 \%$ & 20 \\
\hline Solar + Ground source HP ${ }^{8}$ & Solar + Electricity & $0.87+5414$ & $2.10+0.01$ & 0.00 & 20 \\
\hline Water source $\mathrm{HP}^{8}$ & Electricity & 4353.28 & $1 \%$ & $0 \%$ & 20 \\
\hline Natural gas boiler & NG & 0.10 & 2.34 & 0.00 & 20 \\
\hline Electric boiler & Electricity & 0.98 & 0.46 & 0.00 & 30 \\
\hline
\end{tabular}

${ }^{\mathrm{a}}$ The costs of auxiliary plant equipment are included.

${ }^{b}$ Unless the units are stated otherwise in the footnotes below. Furthermore, for technology combinations, the specific costs given in the form $\mathrm{X}+\mathrm{Y}$ must not be added. The overall specific costs will be the weighted sum and depend on the potential share of each technology (refer to "Potential energy resources").

${ }^{1}$ The investment costs of wood and straw technologies include 2 days of fuel storage.

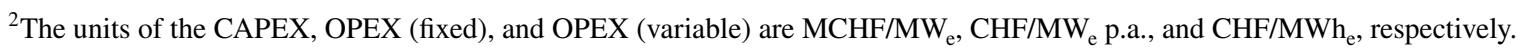

${ }^{3}$ The investment costs include the costs of biomass gasifier for the Stirling engines plant.

${ }^{4}$ The investment costs include the costs of biomass gasifier and biogas upgrade facility.

${ }^{5}$ The units of the CAPEX, OPEX (fixed), and OPEX (variable) are CHF/MWh ${ }_{\text {th }}, \mathrm{CHF} / \mathrm{MWh}_{\mathrm{th}}$ p.a., and CHF/MWh ${ }_{\mathrm{th}}$, respectively. The plant for solar thermal heat includes diurnal storage.

${ }^{6} \mathrm{COP}$ of electric HP is assumed 4.2 .

${ }^{7}$ With heat regeneration.

${ }^{8}$ The units of the CAPEX and OPEX (fixed and variable) of HP technologies are CHF/kW $\mathrm{k}_{\text {th }}$ and \% of investment costs, respectively.

costs and high linear heat density in urban areas like Geneva; however, the size of the network is subject to availability of substantial IEH resources nearby.
IEH-based DHN in combination with another system as a backup for peak load is currently not competitive with decentralized heating. Among the decentralized 


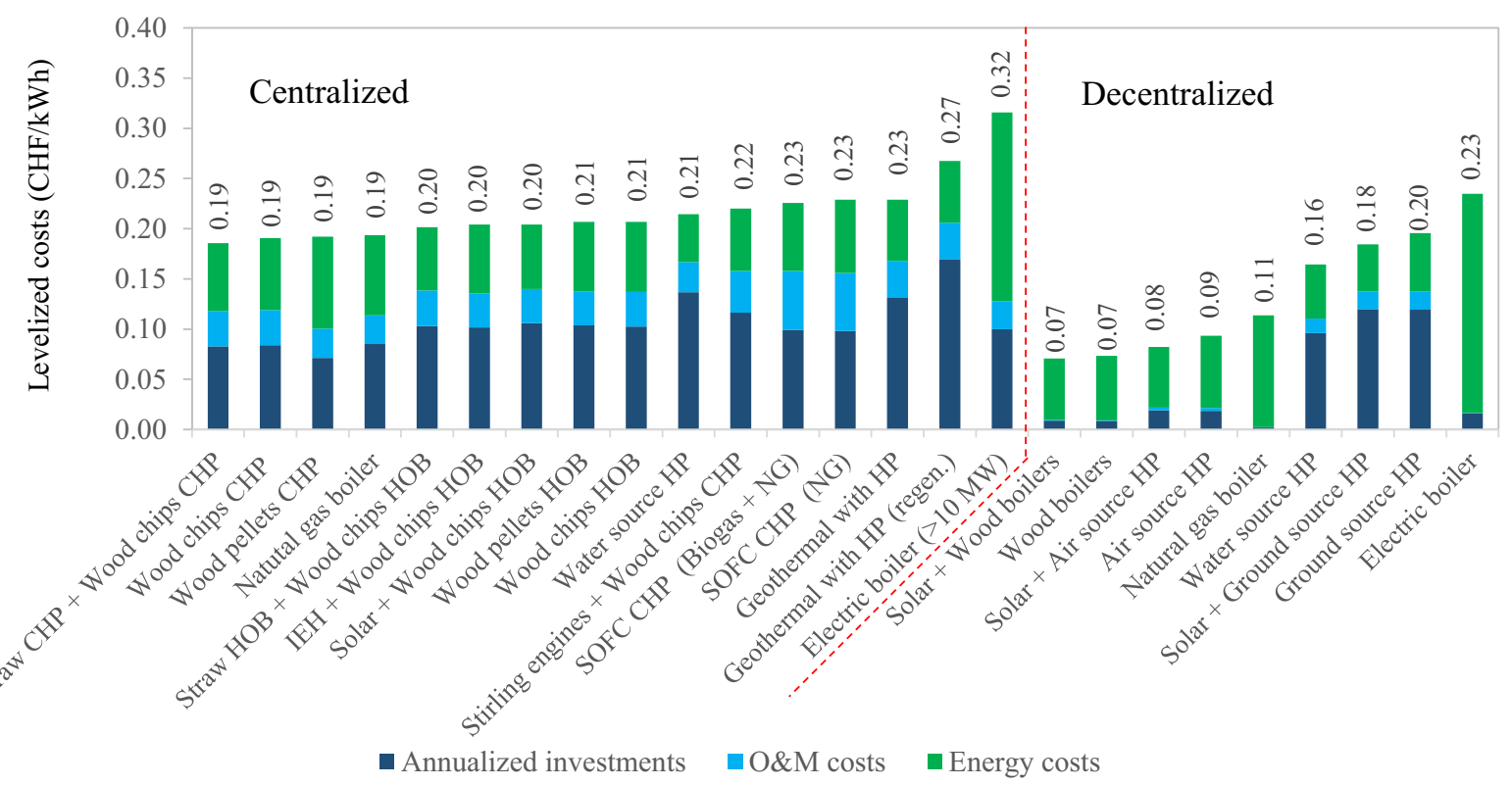

Fig. 2 Levelized costs of energy for the different centralized and decentralized heating technologies and technology combinations (For CHP, the energy supply is much higher, i.e., heat and electricity. Hence, per kWh of energy supply (heat +

heating options, the systems characterized by low levelized costs are wood boilers and ASHPs.

As also shown in Fig. 2, investment costs make up the majority of the levelized costs of most of the centralized and some of the decentralized heating technologies (such as water and ground source heat pumps). For emerging technologies, the costs are generally expected to slightly decrease over time due to technological maturity. However, for solar thermal and heat pumps, IRENA (2017) expects the investment costs to decline more significantly until 2030. Similarly, the National Renewable Energy Laboratory (NREL) in the USA anticipates that the prices for ASHP will drop by $20-38 \%$ in 2050 (Kaufman et al. 2019). According to the Danish Energy Agency $(2018,2020)$, the costs for different heating technologies are expected to decrease by $11-15 \%$ in 2050 from the level in 2020. Along with the investment costs, fuel costs are another important cost driver as shown in Fig. 2. To promote the electrification of the electricity for CHP and only heat for NG boiler), the levelized investment of, for example, wood-pellets CHP is lower than the NG boiler)

Swiss residential heating sector, electricity prices, which are currently high in Switzerland, need to be lowered. However, for deep decarbonization of the sector, the carbon intensity of the Swiss electricity supply should either remain at the current level (because most of it is produced in hydroelectric and nuclear power plants, i.e., $>90 \%$ ("Energy - Facts and Figures" n.d.)) or decrease further. Since Switzerland aims to withdraw from nuclear energy by 2050, the low carbon intensity of the electricity produced in the country can only be ensured by deploying renewable technologies in the power sector. The costs of renewable power generation technologies are decreasing faster than expected (Gielen et al. 2019), which may make it possible that electricity prices to reduce in the future which will ultimately offer greater flexibility of future decarbonization options.

Figure 3 presents the specific $\mathrm{CO}_{2}$ emissions from the various heating technologies and combinations. Since all solar and biomass (including wood)-based 


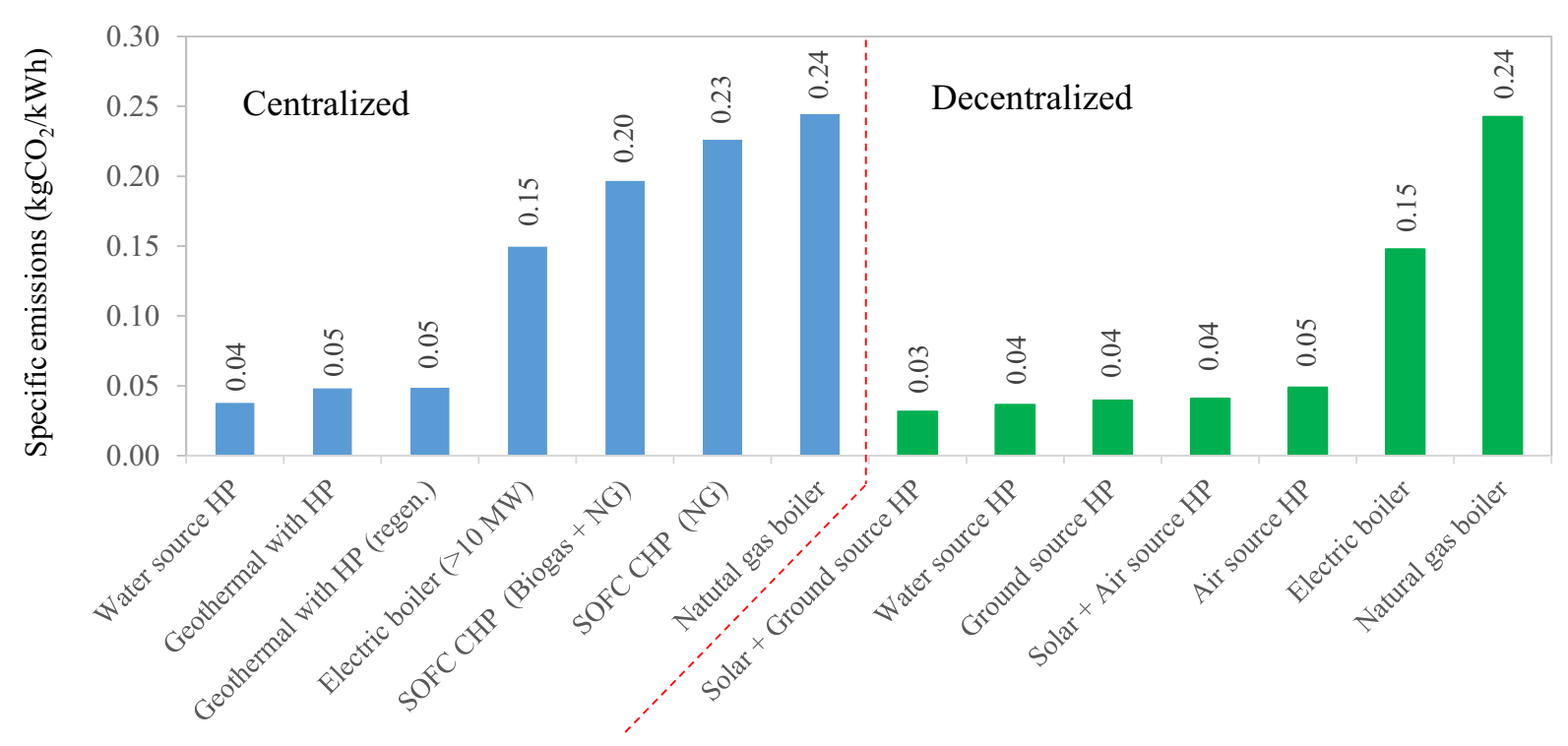

Fig. 3 Specific $\mathrm{CO}_{2}$ emissions for the different centralized and decentralized heating technologies and technology combinations

technologies have almost zero emissions (except for some due to auxiliary plant electricity use), they are not shown in the figure. Heat pumps, geothermal, and electric boilers require electricity for their operation. Since the current $\mathrm{CO}_{2}$ intensity of electricity generation in Switzerland is anyway very low (refer to Table 4 for the reason explained above), all the electrification options are characterized by significantly lower $\mathrm{CO}_{2}$ emissions per unit of heat supply than gas boilers. Inefficiencies of the natural gas boilers in the form of thermal losses further add to the $\mathrm{CO}_{2}$ inventory. On average, the replacement of gas boilers with electrification technologies can result in a sixfold reduction in specific $\mathrm{CO}_{2}$ emissions.

To reach net-zero $\mathrm{CO}_{2}$ emissions by 2050 , oiland gas-fired boilers need to be rapidly replaced by zero-carbon technologies. To this end, the prohibition of the installation of fossil fuel boilers seems to emerge as the primary policy measure in Switzerland (e.g., in Basel based on the Energy Law (Kanton Basel-Stadt n.d.) and in Geneva based on the Plan directeur des énergies (PDE) (GE.CH - République et canton de Genève 2018)). In urban conglomerates, decentralized heating systems based on wood combustion are typically not accepted by the authorities for reasons of air pollution. It will therefore not be possible to rely only on the lowest-cost solutions. According to the results in Figs. 2 and 3, the main technology solutions for decarbonization of the residential heating sector in the short-to-medium term will hence be centralized wood boilers and wood-fired CHP systems as well as centralized and decentralized heat pump technologies. The carbon emissions of heat pump systems are very low in Switzerland (see Fig. 3) and could even be zero if $100 \%$ renewable electricity is used. However, heat pumps have drawbacks of their own (e.g., high CAPEX and space needs) as is the case for wood-based heating systems (e.g., higher space requirements of the conversion unit itself and for wood storage, constant wood supply incurring delivery costs and risks; wood biomass supply in Switzerland is rather constrained due to ecological restrictions (Steubing et al. 2010)). These further characteristics as well as the greater familiarity of the residents with conventional boiler systems have been proven to be a major obstacle to the diffusion of 
Table 8 Electricity grid reinforcement costs for Geneva region to support peak electricity supply.

\begin{tabular}{lll}
\hline Technology & $\begin{array}{l}\text { Electricity grid reinforcement } \\
\text { costs (min) }\end{array}$ & $\begin{array}{l}\text { Electricity grid } \\
\text { reinforcement costs } \\
\text { (max) }\end{array}$ \\
\hline Centralized heating & MCHF & MCHF \\
Water source HP & 13 & 22 \\
Geothermal with HP & 12 & 22 \\
Electric boiler (>10 MW) & 52 & 93 \\
Decentralized heating & & 31 \\
Air source HP & 17 & 23 \\
Water source HP & 13 & 25 \\
Ground source HP & 14 & 93 \\
Electric boiler & 52 & \\
\hline
\end{tabular}

alternative technologies, hence calling for new policy measures.

Costs of electricity grid reinforcement.

As discussed earlier, heat pumps using various heat sources (including geothermal energy) are the major electrification options for decarbonization of the residential heating sector but their current implementation is low. Hence, as the share of electricity-based technologies in the overall heat supply increases, reinforcement of the existing electricity grid distribution and transmission will be required incurring additional investment costs. Based on the estimates given in Table 5, grid reinforcement capital costs are estimated for the case study region and presented in Table 8. While the capital costs of ASHPs are relatively low, the corresponding grid reinforcement costs are higher than for the other types of heat pumps as shown in Table 8 due to the lower SPF; refer to Table 2. Despite the electrification of the energy demand for space heating and hot water, electricity demand may slightly decrease in the future as a result of the building energy efficiency gains (retrofits). Besides, it has not been considered that the current electricity grid could be underutilized (unused capacity). Hence, the grid reinforcement costs displayed in Table 8 are rather conservative.

With the current electricity prices, the levelized costs of ASHP are approximately $20 \%$ lower than the costs of a decentralized gas boiler (see Fig. 2). However, the levelized costs of ASHP could rise if the electricity price has to be raised as a result of the capital investment in the grid expansion. This implies that ASHP may not be competitive in the future if either the $\mathrm{CO}_{2}$ penalty on natural gas consumption is not increased or the subsequent electricity tariff is not subsidized. Finally, the assumptions about specific grid costs made in this study (refer to Table 5) are in good agreement with the results of Gupta et al. (2020) for urban and suburban settings like Geneva. However, their results further show that the specific grid costs in a rural setting could be 15 times higher than the average costs in an urban region. This means that electrification of the heating sector in rural areas could be very expensive and economically challenging. Hence, in these cases, (decentralized) biomass wood boilers could be a favorable solution in terms of cost-effectiveness.

\section{Conclusions}

Addressing the global issue of climate change, this research provides comprehensive information about the key decentralized and district heating technologies for the decarbonization of the residential sector. The results for the case study region show that decarbonization and electrification of the residential heat supply with a dominant contribution from 
renewables are economically feasible, with levelized costs of the most economical renewable energy options (including heat pumps) being close to those of natural gas-fired systems, at least for centralized systems. On the other hand, most renewable energy systems are more expensive than natural gas-based systems. Wood-fired systems are found to be among the most affordable solutions. Since they are, however, implemented cautiously for reasons of air pollution, resource availability and logistics, more expansive renewable heat technologies will also be required. Therefore, overall costs for decarbonized heating can be expected to lie clearly above today's fossil fuel systems. On the other hand, as stated earlier, the investment costs for different heating technologies are expected to decrease in the future. This cost reduction may slightly improve the economic viability of the studied heating systems in the future, while higher cost likely prevails in the short to medium term. The development of scenarios based on future costs (which are highly uncertain for the upcoming technologies, as they are for the energy costs) is planned for future research.

This study presents a comprehensive dataset for investment and O\&M costs for a range of low carbon heating technologies. In this study, the comparison between technologies was performed for a small-case study. However, heating needs are very heterogeneous, depending for instance on the local makeup of the building stock and the availability of various resources. Therefore, future work should consider the system comparisons over a much wider variety of locations and conditions, for instance through geospatial studies of supply and demand options. This would build notably on the authors' previous work (Chambers et al. 2020) where the local variation for the utilization of industrial waste heat technology option was studied. This could be expanded to the full range of options discussed in the present work.

To achieve deep decarbonization of the sector by 2050, a radical shift from conventional fossil fuel boilers to electrification via heat pumps and/ or the introduction of thermal energy networks utilizing cheap local resources like industrial excess heat is required. Besides, the replacement of natural gas boilers with electrification technologies may also result in a sixfold reduction in $\mathrm{CO}_{2}$ emissions. Wide-scale implementation of heat pumps will also require incentives for household owners to switch to low carbon technologies and significant electricity grid reinforcement. Large-scale district heating systems require a sustainable financing mechanism as they are currently relatively expensive due to the high network costs, i.e., approximately $50 \%$ of the total system costs. Finally, to accelerate the clean energy transition, the federal and local governments need to step up their efforts and introduce additional policy instruments such as the prohibition of fossil fuel-based systems or their impeded implementation (e.g., by requiring a minimum share of renewables when replacing a fossil fuel boiler), other regulatory measures (e.g., increasing $\mathrm{CO}_{2}$ tax levels or setting a maximum $\mathrm{CO}_{2}$ emission level for the replacement of heating systems), training of installers and other trades as well as subsidies for the promotion of decarbonization technologies. The adequate mix of policy measures depends on a large number of parameters (e.g., thermal performance of the existing building stock, income level and wealth of tenants and owners, affordable subsidy levels, and political orientation of population), likewise calling for further research.

Funding Open access funding provided by University of Geneva. This research was financially supported by the Swiss Innovation Agency Innosuisse and is part of the Swiss Competence Center for Energy Research - Future Energy Efficient Buildings and Districts (FEEB\&D; Contract no. 1155002539) as well as Joint Activity Scenario and Modeling (JAS\&M; Contract no. 1155003084). The opinions and conclusions of the authors do not necessarily reflect the views of any of the data providers or any other organization.

\section{Declarations}

Competing interests The authors declare no competing interests.

Open Access This article is licensed under a Creative Commons Attribution 4.0 International License, which permits use, sharing, adaptation, distribution and reproduction in any medium or format, as long as you give appropriate credit to the original author(s) and the source, provide a link to the Creative Commons licence, and indicate if changes were made. The images or other third party material in this article are included in the article's Creative Commons licence, unless indicated otherwise in a credit line to the material. If material is not included in the article's Creative Commons licence and your intended use is not permitted by statutory regulation or exceeds the permitted use, you will need to obtain permission directly from the copyright holder. To view a copy of this licence, visit http://creativecommons.org/licenses/by/4.0/. 


\section{Appendix. Levelized costs of energy for the different centralized heating production units.}

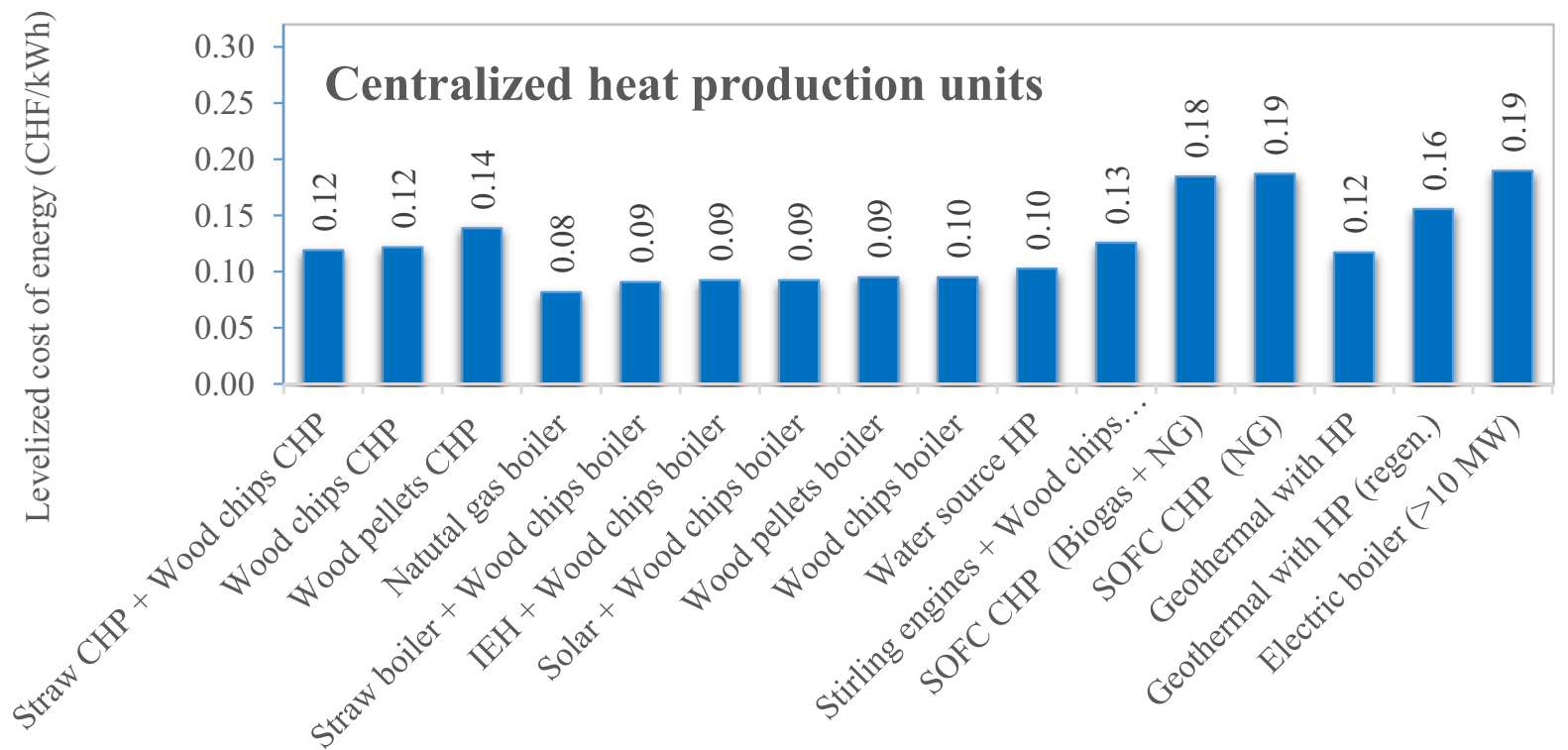

Fig. 4 Levelized costs of energy for the different centralized heating production units.

\section{References}

Ali, S. H., Zuberi, M. J. S., Tariq, M. A., Baker, D., \& Mohiuddin, A. (2015). A study to incorporate renewable energy technologies into the power portfolio of Karachi, Pakistan. Renewable and Sustainable Energy Reviews, 47, 14-22.

BAFU. (2016). Umweltbilanz Strommix Schweiz 2014. https:// www.bafu.admin.ch/bafu/fr/home/themes/climat/chang ements-climatiques\%2D\%2D-questions-et-reponse.html. Accessed 12 Mar 2021.

Ballantine, A. (2019). Everything you need to know about solid oxide fuel cells. Bloom Energy. https://www.bloomenergy. $\mathrm{com} / \mathrm{blog} /$ everything-you-need-know-about-solid-oxidefuel-cells. Accessed 10 Jun 2020.

Batzias, F. A., Sidiras, D. K., \& Spyrou, E. K. (2005). Evaluating livestock manures for biogas production: A GIS based method. Renewable Energy, 30(8), 1161-1176. https:// doi.org/10.1016/j.renene.2004.10.001

BFE. (2018). Analyze des schweizerischen Energieverbrauchs 2000-2017 nach Verwendungszwecken. Bern. https:// www.bfe.admin.ch/bfe/en/home/supply/statistics-andgeodata/energy-statistics/analysis-of-energy-consumptionby-specific-use.html. Accessed 16 January 2018.

Bloess, A., Schill, W.-P., \& Zerrahn, A. (2018). Power-toheat for renewable energy integration: A review of technologies, modeling approaches, and flexibility potentials.
Applied Energy, 212, 1611-1626. https://doi.org/10. 1016/j.apenergy.2017.12.073

Chambers, J., Zuberi, S., Jibran, M., Narula, K., \& Patel, M. K. (2020). Spatiotemporal analysis of industrial excess heat supply for district heat networks in Switzerland. Energy, 192, 116,705. https://doi.org/10.1016/j.energy.2019. 116705

Connolly, D., Lund, H., Mathiesen, B. V., Werner, S., Möller, B., Persson, U., et al. (2014). Heat roadmap Europe: Combining district heating with heat savings to decarbonise the EU energy system. Energy Policy, 65, 475-489. https://doi.org/10.1016/j.enpol.2013.10.035

Danish Energy Agency. (2018). Technology data for individual heating plants. https://ens.dk/en/our-services/ projections-and-models/technology-data/technologydata-individual-heating-plants. Accessed 3 June 2020.

Danish Energy Agency. (2020). Technology data for generation of electricity and district heating. https://ens.dk/en/ourservices/projections-and-models/technology-data/techn ology-data-generation-electricity-and. Accessed 3 June 2020.

Element Energy \& E4tech. (2018). Cost analysis of future heat infrastructure (p. 105). National Infrastructure Commission. https://www.nic.org.uk/publications/cost-analysisof-future-heat-infrastructure/. Accessed 16 June 2020. 
Energy - Facts and figures. (n.d.). https://www.eda.admin.ch/ aboutswitzerland/en/home/wirtschaft/energie/energie \% 2D\%2D-fakten-und-zahlen.html. Accessed 8 Oct 2019.

FOEN. (2018). Switzerland's Greenhouse Gas Inventory 19902016. Bern. https://www.bafu.admin.ch/bafu/en/home/ topics/climate/state/data/climate-reporting/most-recentghg-inventory.html. Accessed 26 Oct 2018.

FSO. (2019). Employees, farmholdings, utilized agricultural area and livestock on level 1 of classification by canton 1975-2018 I Table. Federal Statistical Office. https://www. bfs.admin.ch/bfs/en/home/statistiken/land-forstwirtschaft. assetdetail.8346720.html. Accessed 15 June 2020.

GE.CH - République et canton de Genève. (2018). Planifier l'énergie à l'échelle du territoire. GE.CH - République et canton de Genève. https://www.ge.ch/planifier-energieechelle-du-territoire. Accessed 8 Sept 2020.

Gielen, D., Boshell, F., Saygin, D., Bazilian, M. D., Wagner, N., \& Gorini, R. (2019). The role of renewable energy in the global energy transformation. Energy Strategy Reviews, 24, 38-50. https://doi.org/10.1016/j.esr.2019.01. 006

Gupta, R., Pena Bello, A., Streicher, K. N., Roduner, C., Thöni, D., Patel, M. K., \& Parra, D. (2020). Spatial analysis of distribution grid capacity and costs to enable massive deployment of PV, electric mobility and electric heating.

Hansen, K. (2019). Decision-making based on energy costs: Comparing levelized cost of energy and energy system costs. Energy Strategy Reviews, 24, 68-82. https://doi.org/ 10.1016/j.esr.2019.02.003

Industrial Heat Pumps. (n.d.). How it works. https://industrial heatpumps.nl/en/how_it_works/. Accessed 11 June 2020.

IRENA. (2017). Renewable energy in district heating and cooling: A sector roadmap for Remap. Abu Dhabi. /publications/2017/Mar/Renewable-energy-in-district-heatingand-cooling. Accessed 3 Oct 2019.

Kanton Basel-Stadt. (n.d.). SG 772.100 - Energiegesetz (EnG). https://www.gesetzessammlung.bs.ch/app/de/texts_of_ law/772.100. Accessed 8 Sept 2020.

Kaufman, N., Sandalow, D., Rossi di Schio, C., \& Higdon, J. (2019). Decarbonizing space heating with air source heat pumps: Columbia - Center on Global Energy Policy. https://energypolicy.columbia.edu/research/report/decar bonizing-space-heating-air-source-heat-pumps. Accessed 12 Mar 2021.

Klinke, S. (2018). The determinants for adoption of energy supply contracting: Empirical evidence from the Swiss market. Energy Policy, 118, 221-231. https://doi.org/10. 1016/j.enpol.2018.03.055

Kontu, K., Rinne, S., \& Junnila, S. (2019). Introducing modern heat pumps to existing district heating systems - Global lessons from viable decarbonizing of district heating in Finland. Energy, 166, 862-870. https://doi.org/10.1016/j. energy.2018.10.077

Leibowicz, B. D., Lanham, C. M., Brozynski, M. T., VázquezCanteli, J. R., Castejón, N. C., \& Nagy, Z. (2018). Optimal decarbonization pathways for urban residential building energy services. Applied Energy, 230, 1311-1325. https:// doi.org/10.1016/j.apenergy.2018.09.046

Lund, H., Möller, B., Mathiesen, B. V., \& Dyrelund, A. (2010). The role of district heating in future renewable energy systems. Energy, 35(3), 1381-1390. https://doi.org/10. 1016/j.energy.2009.11.023

Mazurkiewicz, J., Marczuk, A., Pochwatka, P., \& Kujawa, S. (2019). Maize straw as a valuable energetic material for biogas plant feeding. Materials, 12(23). https://doi.org/10. 3390/ma12233848

MeteoSwiss. (2018). Data portal for teaching and research. https://www.meteoswiss.admin.ch/home/services-andpublications/beratung-und-service/datenportal-fuer-lehreund-forschung.html. Accessed 29 Sept 2020.

Narula, K., De Oliveira Filho, F., Chambers, J., Romano, E., Hollmuller, P., \& Patel, M. K. (2020a). Assessment of techno-economic feasibility of centralized seasonal thermal energy storage for decarbonising the Swiss residential heating sector. Renewable Energy, 161, 1209-1225. https://doi.org/10.1016/j.renene.2020.06.099

Narula, K., de Oliveira Filho, F., Villasmil, W., \& Patel, M. K. (2020b). Simulation method for assessing hourly energy flows in district heating system with seasonal thermal energy storage. Renewable Energy, 151, 1250-1268. https://doi.org/10.1016/j.renene.2019.11.121

Newton, P. W., \& Tucker, S. N. (2011). Pathways to decarbonizing the housing sector: a scenario analysis. Building Research \& Information, 39(1), 34-50. https://doi.org/10. 1080/09613218.2010.531085

Panos, E., \& Kannan, R. (2016). The role of domestic biomass in electricity, heat and grid balancing markets in Switzerland. Energy, 112, 1120-1138. https://doi.org/10.1016/j. energy.2016.06.107

Prognos AG/BFE. (2012). Die Energieperspektiven für die Schweiz bis 2050. Basel: BFE. http://www.bfe.admin. $\mathrm{ch} /$ themen/00526/00527/index.html?dossierid $=05024 \&$ lang=de. Accessed 11 Jun 2020.

Quiquerez, L. (2017). Décarboner le système énergétique à l'aide des réseaux de chaleur: état des lieux et scénarios prospectifs pour le canton de Genève. University of Geneva. Retrieved from https://archive-ouverte.unige.ch/ unige:93380. Accessed 10 Jun 2020.

République et canton de Genève. (2018). GEothermie 2020: une journée portes ouvertes pour dévoiler les résultats du premier forage exploratoire de Satigny. GE.CH - République et canton de Genève. https://www.ge.ch/document/ geothermie-2020-journee-portes-ouvertes-devoiler-resul tats-du-premier-forage-exploratoire-satigny. Accessed 5 June 2020.

Sandvall, A. F., Ahlgren, E. O., \& Ekvall, T. (2017). Costefficiency of urban heating strategies - Modeling scale effects of low-energy building heat supply. Energy Strategy Reviews, 18, 212-223. https://doi.org/10.1016/j.esr. 2017.10.003

Schneider, S., Hollmuller, P., Chambers, J., \& Patel, M. (2019). A heat demand load curve model of the Swiss National Territory. IOP Conference Series: Earth and Environmental Science, 290(1), 012107. https://doi.org/10.1088/17551315/290/1/012107

SDSN/IDDRI. (2014). Pathways to deep decarbonization. Accessed 12 Mar 2021.

SIG. (2019). GeniLac, le plus grand réseau thermique écologique. https://ww2.sig-ge.ch/actualites/genilac-leplus-grand-reseau-thermique-ecologique. Accessed 11 June 2020. 
Steubing, B., Zah, R., Waeger, P., \& Ludwig, C. (2010). Bioenergy in Switzerland: Assessing the domestic sustainable biomass potential. Renewable and Sustainable Energy Reviews, 14(8), 2256-2265.

STIG. (2015). Catalog. https://ge.ch/sitg/sitg_catalog/sitg_ donnees/i?keyword=IDC. Accessed 29 Sept 2020.

Streicher, K. N., Padey, P., Parra, D., Bürer, M. C., \& Patel, M. K. (2018). Assessment of the current thermal performance level of the Swiss residential building stock: Statistical analysis of energy performance certificates. Energy and Buildings, 178, 360-378. https://doi.org/10.1016/j.enbui ld.2018.08.032

Streicher, K. N., Padey, P., Parra, D., Bürer, M. C., Schneider, S., \& Patel, M. K. (2019). Analysis of space heating demand in the Swiss residential building stock: Elementbased bottom-up model of archetype buildings. Energy and Buildings, 184, 300-322. https://doi.org/10.1016/j. enbuild.2018.12.011

Timmons, D., Konstantinidis, C., Shapiro, A. M., \& Wilson, A. (2016). Decarbonizing residential building energy: A cost-effective approach. Energy Policy, 92, 382-392. https://doi.org/10.1016/j.enpol.2016.02.030

World Energy Council. (2013). World Energy Resources: 2013 Survey. https://www.worldenergy.org/assets/images/impor ted/2013/09/Complete_WER_2013_Survey.pdf. Accessed 11 Jun 2020.
Zbytek, Z., Dach, J., Pawłowski, T., Smurzyńska, A., Czekała, W., \& Janczak, D. (2016). Energy and economic potential of maize straw used for biofuels production. MATEC Web of Conferences, 60, 04008. https://doi.org/10.1051/matec conf $/ 20166004008$

Zhang, H., Zhou, L., Huang, X., \& Zhang, X. (2019). Decarbonizing a large City's heating system using heat pumps: A case study of Beijing. Energy, 186, 115,820. https://doi. org/10.1016/j.energy.2019.07.150

Zuberi, M. J. S., Bless, F., Chambers, J., Arpagaus, C., Bertsch, S. S., \& Patel, M. K. (2018). Excess heat recovery: An invisible energy resource for the Swiss industry sector. Applied Energy, 228, 390-408. https://doi.org/10.1016/j. apenergy.2018.06.070

Zuberi, M. J. S., Narula, K., Klinke, S., Chambers, J., Streicher, K. N., \& Patel, M. K. (2021). Potential and costs of decentralized heat pumps and thermal networks in Swiss residential areas. International Journal of Energy Research, 1-20. https://doi.org/10.1002/er.6801

Publisher's note Springer Nature remains neutral with regard to jurisdictional claims in published maps and institutional affiliations. 